\title{
Author Correction: Response outcomes gate the impact of expectations on perceptual decisions
}

\author{
Ainhoa Hermoso-Mendizabal (1D), Alexandre Hyafil (D), Pavel E. Rueda-Orozco (D), Santiago Jaramillo (1), \\ David Robbe (1) \& Jaime de la Rocha (1)
}

Correction to: Nature Communications https://doi.org/10.1038/s41467-020-14824-w, published online 26 February 2020.

The original version of the Supplementary Information file associated with this Article contained several errors in the Supplementary Methods due to text being inadvertently removed during the revision process. The HTML has been updated to include a corrected version of the Supplementary Information.

Published online: 07 July 2020

(c) Open Access This article is licensed under a Creative Commons Attribution 4.0 International License, which permits use, sharing, adaptation, distribution and reproduction in any medium or format, as long as you give appropriate credit to the original author(s) and the source, provide a link to the Creative Commons license, and indicate if changes were made. The images or other third party material in this article are included in the article's Creative Commons license, unless indicated otherwise in a credit line to the material. If material is not included in the article's Creative Commons license and your intended use is not permitted by statutory regulation or exceeds the permitted use, you will need to obtain permission directly from the copyright holder. To view a copy of this license, visit http://creativecommons.org/licenses/by/4.0/.

(C) The Author(s) 2020 